Article

\title{
Biological Aspects of Mountain Pine Beetle in Lodgepole Pine Stands of Different Densities in Colorado, USA
}

\author{
José F. Negrón \\ USDA Forest Service, Rocky Mountain Research Station, 240 West Prospect, Fort Collins, CO 80526, USA; \\ jnegron@fs.fed.us; Tel.: +1-970-498-1252
}

Received: 9 November 2018; Accepted: 24 December 2018; Published: 29 December 2018

check for updates

\begin{abstract}
Research Highlights: The biology of mountain pine beetle (MPB), Dendroctonus ponderosae Hopkins, in Colorado's lodgepole pine forests exhibits similarities and differences to other parts of its range. Brood emergence was not influenced by stand density nor related to tree diameter. The probability of individual tree attack is influenced by stocking and tree size. Findings have implications for understanding MPB as a disturbance agent and for developing management strategies. Background and Objectives: MPB causes extensive tree mortality of lodgepole pine, Pinus contorta Douglas ex Loudon, across the western US and Canada and is probably the most studied bark beetle in North America. However, most of the current knowledge on the biology and ecology of MPB in lodgepole pine comes from the Intermountain Region of the US and western Canada. Little information is available from Colorado. This is the first study addressing effects of stand stocking levels on the biology of MPB and quantifying phloem consumption. In addition, although data are available on the conditions that foster stand infestation, this is the first study estimating the probability of individual tree attack among stands of known different stocking. Materials and Methods: Studies were conducted in managed lodgepole pine stands in Colorado. Unbaited traps were used to monitor MPB flight across stands of different densities. Cages were used to monitor emergence and bark samples to determine attack densities, and phloem consumption in trees growing under different stocking. Beetle collections were used to determine emergence across the growing season. Tree mortality data from plots of different densities were used to examine the probability of individual tree infestation. Results: More beetles were caught flying through higher density stands. More attacks were observed in lower stocking stands but there were no differences in the number of insects emerging nor phloem consumption. There was no relationship between tree size and beetle emergence. Peak flight occurred in early to mid-August and only one peak of beetle emergence occurred. The probability of tree attack was influenced by stand stocking and tree diameter. Conclusions: In general, aspects of the biology of MPB in Colorado exhibit similarities and differences with other regions. The data suggest the need to more closely examine how MPB functions in stands of different stocking and how the distribution of tree sizes influence the probability of infestation and extent of mortality in stands. Biological characteristics of MPB in Colorado need further examination, particularly as climate change continues to manifest. Baseline information will be critical to refine management approaches, and extend the understanding of how MPB contributes to shape forest composition and structure in Colorado.
\end{abstract}

Keywords: Dendroctonus ponderosae; Pinus contorta; bark beetles 


\section{Introduction}

The mountain pine beetle (MPB), Dendroctonus ponderosae Hopkins (Coleoptera: Curculionidae: Scolytinae), is a widely distributed bark beetle in western North America with a geographical range extending from northern Mexico to northwestern British Columbia and from the Pacific Ocean east to the Black Hills of South Dakota [1]. In addition, it has been reported from Nebraska [2] and its range is also expanding eastward in Canada [3] as a result of climate change [4,5]. Many species of pine within its range are hosts for the beetle [1,6,7], however, ponderosa pine, Pinus ponderosa Lawson \& C. Lawson, and lodgepole pine, Pinus contorta Douglas ex Loudon, are the most abundant hosts in western North America. Most bark beetles utilize dead, dying, or weakened hosts for habitat and reproduction but eruptive populations of MPB can cause elevated tree mortality across large landscapes $[1,7,8]$. A native insect and a natural disturbance agent, it contributes to shaping forest structure and composition through tree mortality at multiple scales from single trees to gap dynamics and large-scale landscapes [9-11]. Elevated populations can present challenges for land managers and land owners as dead trees can pose safety hazards in high-value recreation sites, negate silvicultural management investments, and influence wildlife habitat, wildland fires, and hydrologic processes in a variety of ways [12].

A large outbreak caused extensive tree mortality in north-central Colorado beginning in the late 1990s, and by 2012 it had affected about 1.4 million ha of primarily lodgepole pine forests [13]. The outbreak was associated with warm winter temperatures that fostered survival of overwintering populations, an area-wide drought that compromised tree defenses and physiological status, and an abundance of contiguous susceptible host trees and stands across the landscape [12]. Some stands exhibited up to $100 \%$ mortality while others were not affected. On average, tree density and basal area were reduced by $62 \%$ and $71 \%$, respectively, in infested stands and mean tree diameter was reduced by 53\% [11]. MPB prefers high-density stands with trees greater than 20-25 cm in diameter at breast height ( $\mathrm{dbh}$ which is at $1.4 \mathrm{~m}$ above the ground) $[14,15]$. Trees in dense stands exhibit increased stress and reduced defenses while large trees offer abundant resources in the phloem for insect development and population growth [15-20]. Dense stands may also offer a more suitable habitat for MPB by maintaining moderate temperatures that may reduce mortality to high subcortical temperatures, reduce dispersion of insect-produced aggregation pheromones, and provide inter-tree distances that may facilitate infestation development [21-26].

There is a history of MPB outbreaks in Colorado [27,28] yet most studies of MPB in Colorado have been in ponderosa pine, where most outbreaks have occurred $[27,29,30]$. The larger body of knowledge on the biology of MPB in lodgepole pine forests comes from studies in the Intermountain Region in the US and the Canadian Rockies [14,18] with little information available from studies conducted in Colorado. Lodgepole pine forests represent about 7\% of the total forest land in Colorado [31]. Lodgepole pine and subalpine forests on the western slope of Colorado are similar in terms of plant associations and productivity to other locations in the Rockies [32,33] which may foster similar MPB habits. However, there are scant data on the biology and ecology of MPB in Colorado's lodgepole pine forests, although this area has received increased emphasis in recent years as a result of the recent extensive outbreaks. For example, recent studies indicate that emergence from infested trees at different elevations in central Colorado occurs during the first two weeks in August, which is broadly consistent with emergence monitoring from ponderosa pine in Colorado [34-36]. Studies have examined host selection and compared mortality levels between lodgepole and ponderosa pine in mixed stands in the Colorado Front Range (the eastern slope of the Colorado Rockies) [36,37]. Results indicated that although MPB prefers ponderosa pine, both species are susceptible to attack and can experience extensive mortality. An examination of tree growth and stand susceptibility to MPB in partial cut lodgepole pine stands in northern Colorado and southern Wyoming suggested a basal area of $27.5 \mathrm{~m}^{2}$ / ha as a threshold for infestation when trees of suitable size are available [38]. A study conducted in unmanaged stands in Colorado indicated that the probability of lodgepole pine stand 
infestation increased when basal area was $>13.6 \mathrm{~m}^{2} /$ ha and that higher mortality levels occurred when lodgepole pine basal area was $>24.4 \mathrm{~m}^{2} /$ ha [39].

Bark beetles can exhibit differences in habits across their geographical range. For example, although weather conditions can affect flight patterns, the Douglas-fir beetle (DFB), Dendroctonus pseudotsugae Hopkins, exhibited elevated pheromone trap catches in northeastern Oregon from mid-May to early June with a second peak towards the end of July-early August [40]. A second peak in DFB emergence is also indicated elsewhere [41]. In Colorado, two years of emergence trapping with DFB indicated peak emergence on 10 and 26 June and but no second peak in emergence [42]. Also in Colorado, three years of DFB pheromone trapping captured peak numbers of beetles consistently between 22 June and 26 June and again a second peak was not observed [43]. Variations in body size and developmental time have been demonstrated with MPB attributed to geographic location and genetic structure [44,45]. The limited baseline data on biological aspects of the MPB in Colorado assumes elevated importance as global warming continues to manifest. Climate change will have direct and indirect impacts on bark beetle ecology and their hosts, and although larger and more intense outbreaks are expected, the interactions are highly complex and not well-understood [46-49]. This exacerbates the need to collect basic biological information on MPB from Colorado and determine if patterns are consistent or different from other parts of the range of the insect which may support or negate anticipated similar responses to climate change. To enhance our understanding of the biology of MPB in Colorado, I conducted a number of studies during the recent outbreak. Because stand density and stocking levels influence how MPB functions in the forest environment, my objective was also to obtain data in support of management strategies for MPB examining stands of different stocking. Questions addressed included: Does MPB exhibit preference in flying patterns across stands of different densities? Are there differences in MPB attack densities, brood emergence, and phloem consumption in lodgepole pine trees within stands of different densities? Is there a relationship between tree dbh and brood emergence from trees within stands of different densities? Is the probability of individual tree attack greater in dense stands?

\section{Materials and Methods}

\subsection{Study Sites}

Studies were conducted from 2005-2008 at Fraser Experimental Forest (FEF) located in central Colorado within the Arapaho-Roosevelt National Forest (approximate UTM: WGS84 13T 426558, 4420185 and elevation of about $2701 \mathrm{~m}$ ) and in the Colorado State Forest (CSF) in northern Colorado (approximate UTM: WGS84 13T 412098, 4490876, and elevation of about $2661 \mathrm{~m}$ ). The FEF is west of the Continental Divide (CD) while the CSF is east of the CD and west of the Colorado Front Range. Both sites were in relatively level terrain. Precipitation 30-year normal (1981-2010) for FEF was $3.8 \mathrm{~cm}$ in January, $4.6 \mathrm{~cm}$ in July, and $55.5 \mathrm{~cm}$ yearly; mean daily temperature was $-7.3^{\circ} \mathrm{C}$ for January and $13.8^{\circ} \mathrm{C}$ for July. For the CSF site, 30-year normal for precipitation was $3.7 \mathrm{~cm}$ in January, $4.9 \mathrm{~cm}$ in July, and $56.7 \mathrm{~cm}$ yearly; mean daily temperature in January was $-8.3{ }^{\circ} \mathrm{C}$ and $12.8^{\circ} \mathrm{C}$ in July [50].

In the 1970s and 1980s, a series of plots were established in lodgepole pine stands 60-70 years-old to measure the effect of stand density on tree growth and susceptibility to MPB (Mata et al. 2003) [38]. Plots were thinned using the concept of growing stock level (GSL) [38,51]. GSL quantifies the relationship between residual basal area and mean stand diameter but has been infrequently used to characterize stocking. When mean diameter is $\geq 25.4 \mathrm{~cm}$ after thinning GSL equals basal area and when mean diameter after thinning is less than $25.4 \mathrm{~cm}$ GSL is less than basal area [51]. As mean diameter of trees in the plots ranged from 20-30 cm, GSL approximates basal area, but the term GSL as used in the initial plot establishment protocol is retained herein. At the FEF site, plots comprised 0.2 ha and were established in 1975-1980, and included five replicates of GSLs 40, 80, 100, and 120. At the CSF site, a set of plots comprising one plot of GSL 40, 80, and 120 were established in 1985 with each plot comprising 1 ha. All statistical analysis for the experiments below were conducted using SAS software [52]. 


\subsection{Mountain Beetle Flight across Stands with Variable Densities}

To examine MPB flight across stands with different stocking levels, clusters of three Lindgren funnel traps [53] with no bait, were deployed in the center of each of five replicates of GSLs 40, 80, and 120 at FEF. The traps passively caught beetles dispersing through the stands. Beetles were collected in mid-summer and again in the fall following the cessation of beetle flight. The collected beetles were taken to the laboratory where MPB counts were totaled. The mean number of beetles caught among the various GSL plots were compared using a generalized linear mixed model with a negative binomial distribution with GSL and year as the main fixed effects, GSL and year as interaction, and replicate as a random effect.

\subsection{Attack Density, Insect Emergence, and Phloem Consumption}

This phase of the study was conducted using two stand conditions: a high stocking level considered susceptible to MPB (GSL 120) and a low stocking level not considered susceptible to MPB (GSL 40) [38]. To monitor and quantify insect emergence from infested trees, screen cages covering approximately $0.2 \mathrm{~m}^{2}$ with a collecting jar at the bottom were attached to sample trees. Cages were stapled to the north side of successfully infested trees attacked the previous year. Successfully attacked trees had profuse amounts of boring residues completely encircling the tree's root collar, MPB galleries under the bark, and needles fading in coloration [11]. Pitch tubes were infrequent due to the drought which likely compromised tree defenses and reduced resin production. Points of MPB attacks had mostly small accumulations of boring residue. Cages were attached to the north side as a higher density of beetles were associated with that aspect in both lodgepole and ponderosa pine [54-56] although other data suggest higher emergence occurring from the south aspect [57]. Cages were attached to the trees just above dbh in mid-June to early July and insects were collected weekly. In 2007, cages were attached to five infested trees in four replicates of GSL 40 and GSL 120 plots at FEF totaling 20 trees for each GSL. In 2008, cages were attached to 20 trees in each of the 40 and 120 GSL plots at the CSF site. At each location for both years, infested trees were randomly selected from records of available infested trees, while attempting to select trees within a $5 \mathrm{~cm}$ difference in dbh, although this was not always possible. Once adult emergence was completed in the fall, $30 \mathrm{~cm} \times 15 \mathrm{~cm}$ bark samples were extracted from the area covered by the cages. Samples were taken to the laboratory and the number of attacks observed on the underside of the bark were determined. Bark samples from the CSF were also used to measure percent phloem consumption. Samples were photographed with a digital camera and the image superimposed with a digital fine resolution grid. The condition of the phloem was determined as consumed or intact at every grid point within the sample and these data were used as a measurement of the percent of phloem consumption. The number of attacks and the number of beetles collected from the emergence cages were compared between the two GSLs using a negative binomial distribution with GSL as a fixed effect and replicate within years as a random effect. Diameter at breast height was compared between the two GSLs using a generalized linear mixed model with a gamma distribution and GSL as a fixed effect and replicate within years as a random effect. The percent phloem consumed by the beetles was examined for the CSF samples using a generalized linear mixed model with a beta distribution and GSL as fixed effect and individual trees as a random effect. Previous studies indicate increased brood production from larger trees with thicker phloem $[19,20]$. Therefore, the relationship between the number of beetles emerging as a function of tree dbh was also examined using a generalized linear mixed model with a negative binomial distribution and with replicate within year as a random effect and the relationship plotted across both GSLs and for each GSL separately. Weekly emergence data from each location was plotted for both years and examined visually for any differences in emergence timing between stocking levels.

\subsection{Probability of Individual Tree Attack}

At the time of the study, northern Colorado was experiencing an extensive MPB outbreak beginning around 1999 [13] and although extensive mortality was already occurring elsewhere at FEF, 
there were no attacks in the GSL plots until 2004 when two trees were attacked in one of the GSL 100 plots. Beetle attacks increased within the plots in 2005. During the fall of 2005 and again in 2008, we determined the status of trees in each of four 40,80,100, and 120 replicates and recorded trees as live or killed by MPB. No trees died due to other causes during that period, and all MPB-attacked trees were successfully infested. Plots were revisited in 2011, but only limited additional mortality had occurred, so only the 2008 data was used to reduce the temporal effect. Using these data, I modelled the probability of a tree being attacked by MPB as a function of GSL and tree dbh using generalized linear mixed models with a Bernoulli distribution and with replicate as a random effect. Then I examined pairwise comparisons of GSLs for tree dbh from $15 \mathrm{~cm}$ to $35 \mathrm{~cm}$ in $5 \mathrm{~cm}$ increments.

\section{Results}

\subsection{Mountain Beetle Flight across Stands with Variable Densities}

The numbers of beetles caught in the passive traps was different among the GSLs $(F=14.5$, $p<0.0001)$ and years $(F=17.5, p<0.0001)$ but the interaction was not significant $(F=0.4, p>0.78)$ (Table A1). Beetles caught in the passive traps across all years were less in the GSL 40 compared to the GSL 120 (Table 1). There was no difference in the number of beetles caught between GSLs 80 and 120. Across all GSL plots, more beetles were caught in 2006 compared to 2005 and 2007 with no differences between the latter years.

Table 1. Mean (SE) number of Dendroctonus ponderosae beetles caught in passive Lindgren funnel traps (no attractants), in Pinus contorta stands with growing stock levels (GSL) of 40, 80, and 120 across all years and per year across all GSL levels. Three traps were deployed in five replicates of each GSL level. Different letters within columns denote significant differences at $p<0.05$, Tukey's studentized range test, $n=15$ for all GSLs, Fraser Experimental Forest, CO, 2005-2007.

\begin{tabular}{cccc}
\hline GSL & Mean (SE) Number of Beetles & Year & Mean (SE) Number of Beetles \\
\hline 120 & $453.7(139.2) \mathrm{a}$ & 2005 & $127.0(45.5) \mathrm{b}$ \\
80 & $235.4(79.9) \mathrm{a}$ & 2006 & $550.4(140.5) \mathrm{a}$ \\
40 & $92.8(28.0) \mathrm{b}$ & 2007 & $104.5(21.4) \mathrm{b}$ \\
\hline
\end{tabular}

\subsection{Attack Density, Insect Emergence, and Phloem Consumption}

Based on data obtained from bark samples, there were more attacks $(F=10.4, p<0.002)$ on trees growing in the GSL 40 plots compared to the GSL 120 plots. There were no differences in the number of insects emerging from trees between the two stocking levels $(F=0.56, p>0.46)$ (Table 2). Tree dbh of sampled trees was slightly larger in the GSL 40 compared to the GSL $120(F=8.8, p<0.004)$. From the bark samples collected at the CSF, there was no difference in the percent of phloem consumed between the two GSL levels $(F=1.3, p>0.26)$ (Table A2).

Table 2. Mean (SE) Dendroctonus ponderosae (MPB) emergence and attacks per $\mathrm{m}^{2}$, diameter at breast height ( $\mathrm{dbh}$ ) of Pinus contorta sample trees, and phloem consumption in trees in growing stock levels (GSL) 40 and 120,n= 40 for each GSL. All means followed by SE in parenthesis. Different letters across rows indicate significant differences at $p<0.05$, Tukey's studentized range test, Fraser Experimental Forest and Colorado State Forest, CO, 2007-2008.

\begin{tabular}{|c|c|c|}
\hline & GSL 40 & GSL 120 \\
\hline Attacks per $\mathrm{m}^{2}$ & $101.1(6.8) \mathrm{a}$ & $73.6(5.3) \mathrm{b}$ \\
\hline Emerging beetles per $\mathrm{m}^{2}$ & $638.4(92.1) \mathrm{a}$ & $556.8(68.2) \mathrm{a}$ \\
\hline $\mathrm{dbh}(\mathrm{cm})$ & $28.1(0.5) \mathrm{a}$ & $26.2(0.5) b$ \\
\hline Percent phloem consumption ${ }^{1}$ & $49.0(4.7) \mathrm{a}$ & $41.6(2.4) \mathrm{a}$ \\
\hline
\end{tabular}


There was no relationship between the number of emerging beetles and tree $\mathrm{dbh}(F=0.07, p>0.79)$, nor GSL $(F=0.3, p>0.59)$ nor their interaction $(F=0.24, p>0.63)$ (Figure 1a). The plots describing the relationship for each GSL had complete overlap of the $95 \%$ confidence intervals (Figure 1b) (Table A3). Temporal emergence pattern of beetles across the season was the same from trees in the GSL 40 and 120 except that in 2007, emergence in GSL 120 peaked a week later than in GSL 40 (Figure 2a,b). In 2007, peak emergence occurred in late-July to early August and beetles were caught from 13 June, the first date traps were checked, through 19 September. In 2008, peak emergence occurred in late-July to mid-August and beetles were caught from 15 July, the first date traps were checked, through 20 September.
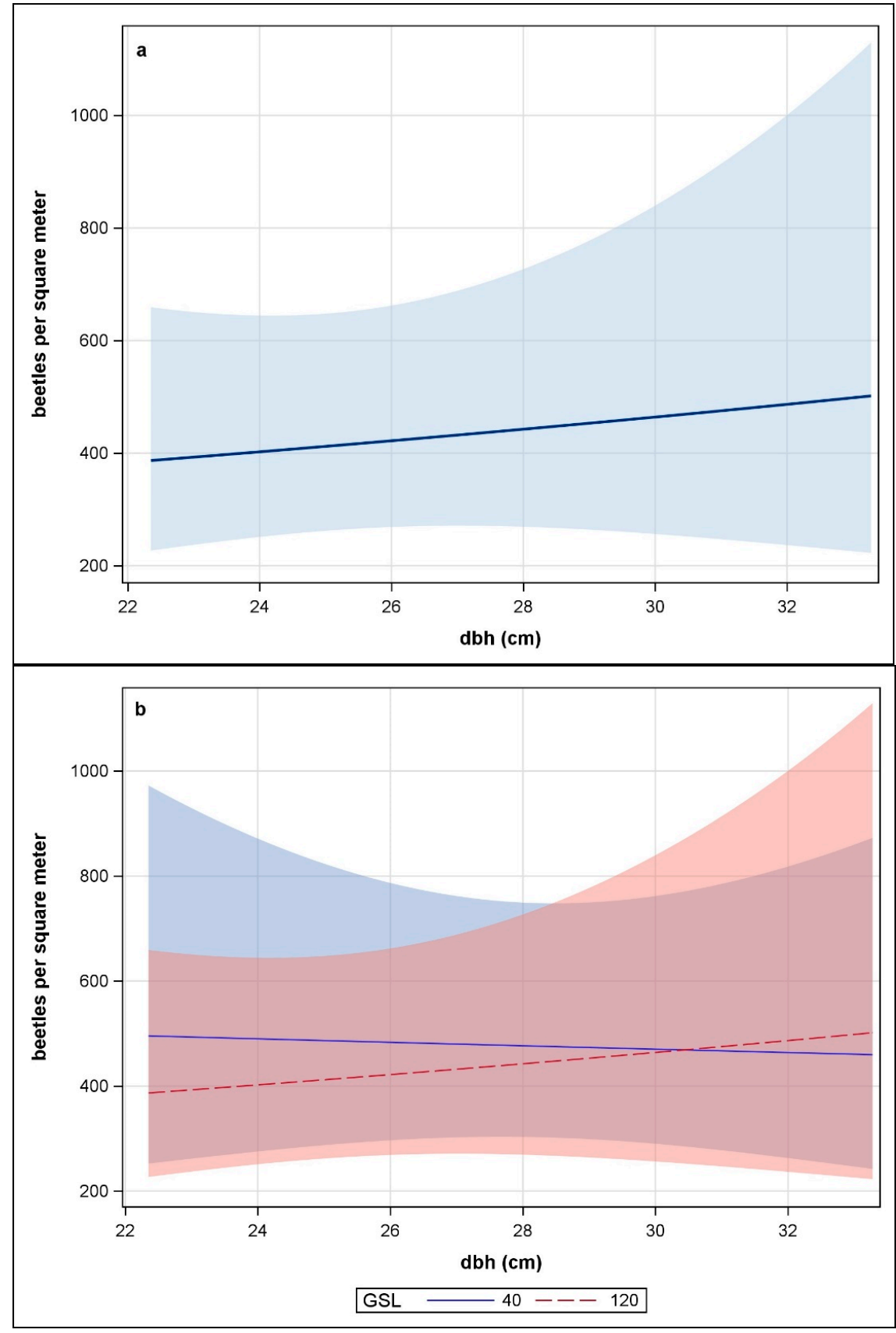

Figure 1. Relationship between number of Dendroctonus ponderosae beetles emerging per square meter from Pinus contorta and tree diameter at breast height $(\mathrm{dbh}$ in $\mathrm{cm})(\mathbf{a})$ across growing stock levels 40 and 120, color band denotes 95\% confidence interval, $n=80$; and (b) and per GSL, color bands denote 95\% confidence intervals, $n=40$ for each GSL, Fraser Experimental Forest and Colorado State Forest, CO, 2007-2008. 

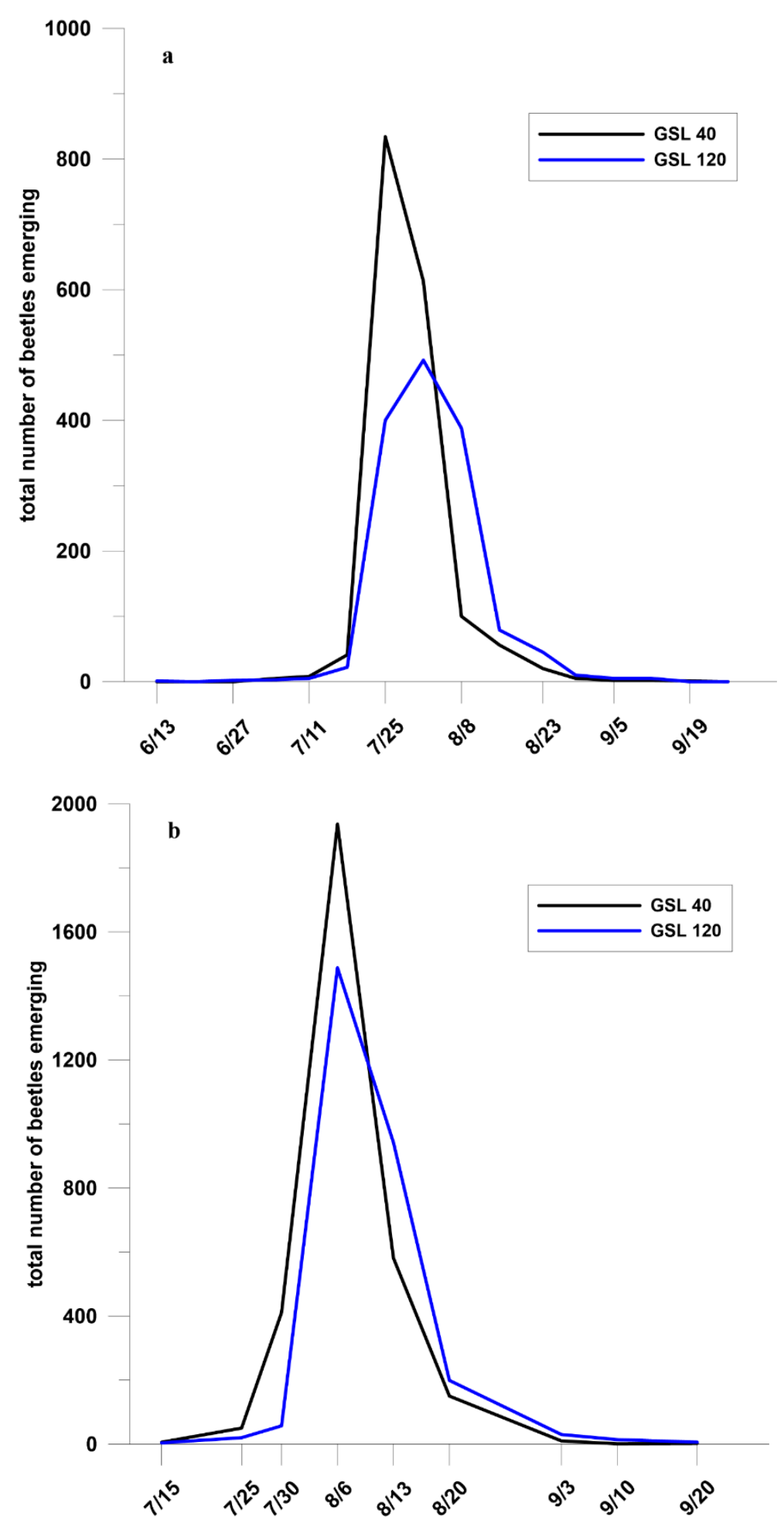

Figure 2. Emergence of Dendroctonus ponderosae from Pinus contorta at growing stock levels 40 and 120, $n=20$ for each GSL, (a) Fraser Experimental Forest, CO, 2007; and (b) Colorado State Forest, CO, 2008.

\subsection{Probability of Individual Tree Attack}

The probability of tree attack was significantly influenced by GSL $(F=8.2, p<0.0001)$ and tree $\operatorname{dbh}(F=105.4, p<0.0001)$ and the interaction was also significant $(F=13.1, p<0.0001)$ (Table A4). For GSL 80, 100, and 120, the probability of tree attack increased with tree diameter but remained constant for GSL 40 across the range of dbh examined (Figure 3). The probability of attack approached 
1 for GSLs 100 and 120 with a dbh of $30 \mathrm{~cm}$ and for GSL 80 with a dbh of $35 \mathrm{~cm}$. As a result of the significant interaction, pairwise differences in the probability of tree attack between GSLs varied across dbh (Table 3).

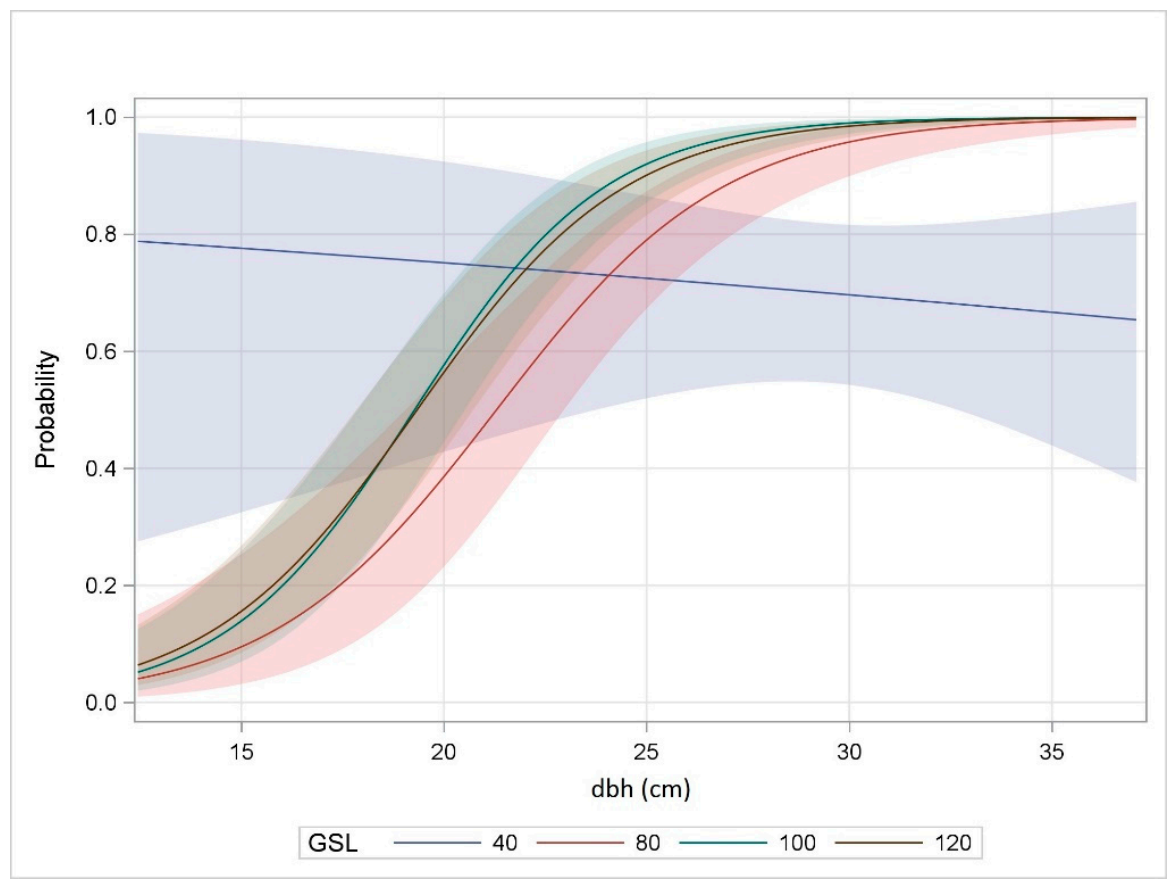

Figure 3. Probability of Dendroctonus ponderosae attacking individual Pinus contorta trees as influenced by growing stock level (GSL) and diameter at breast height (dbh), $n=1415$, Fraser Experimental Forest, CO, 2008.

Table 3. Significance of pairwise comparisons between growing stock levels (GSL) in the probability of Dendroctonus ponderosae attack to Pinus contorta trees at five diameter at breast height sizes, asterisks denote significant differences at $p<0.05$, Tukey's studentized range test, Fraser Experimental Forest, $\mathrm{CO}, 2008$.

\begin{tabular}{cccccc}
\hline \multirow{2}{*}{ GSL } & \multicolumn{5}{c}{ Diameter at Breast Height (cm) } \\
\cline { 2 - 6 } & $\mathbf{1 5} \mathbf{~ c m}$ & $\mathbf{2 0} \mathbf{~ c m}$ & $\mathbf{2 5} \mathbf{~ c m}$ & $\mathbf{3 0} \mathbf{~ c m}$ & $\mathbf{3 5} \mathbf{~ c m}$ \\
\hline 40 vs. 80 & $0.003^{*}$ & 0.063 & 0.774 & $<0.0001 *$ & $<0.0001^{*}$ \\
40 vs. 100 & $0.006^{*}$ & 0.542 & $0.004^{*}$ & $<0.0001 *$ & $<0.0001 *$ \\
40 vs. 120 & $0.007^{*}$ & 0.483 & $0.012^{*}$ & $<0.0001^{*}$ & $<0.0001^{*}$ \\
80 vs. 100 & 0.869 & $0.020 *$ & $0.004^{*}$ & 0.119 & 0.294 \\
80 vs. 120 & 0.699 & $0.028 *$ & $0.013 *$ & 0.264 & 0.534 \\
100 vs. 120 & 0.977 & 0.987 & 0.907 & 0.911 & 0.914 \\
\hline
\end{tabular}

\section{Discussion}

This work appears to be the first study that examines attack densities, brood emergence, and timing of emergence as influenced by stand stocking and to quantify phloem consumption by MPB. It is also the first study to examine the probability of individual tree infestation when trees are growing under different stocking levels. Although a higher density of attacks occurred in more open stands this did not translate to higher emergence rates. No relationship was observed between tree diameter and MPB emergence which differs with previous reports but this may have been associated with high tree stress and a large MPB population. MPB attacks, brood production, and emergence period is broadly consistent with data from other parts of the insect's range. Findings also indicate the importance of considering the distribution of tree sizes in a stand in addition to stocking when evaluating the likelihood of infestation and extent of potential mortality. 


\subsection{Mountain Beetle Flight across Stands with Variable Densities}

MPB exhibited preference for flying through the denser stands examined in this study. Although little data are available on this topic, results of this portion of the study are consistent with observations from other studies. A study in Montana monitored beetle flight for four years in stands thinned to different densities and in unthinned stands using passive traps and reported higher insect catches in unthinned stands compared to thinned stands and that the beetles flew primarily at mid-bole height [58]. In Utah, more MPBs were caught in an unthinned stand compared to a thinned stand using traps baited with MPB attractants [22]. Interestingly, this contrasts with less aggressive species such as the striped ambrosia beetle, Trypodendron lineatum Olivier and pine engravers, Ips pini (Say), which were collected in baited pheromone and window traps at higher frequency in thinned stands [59]. Both of these species prefer drier environments with an abundance of coarse woody debris. This suggests that traps are an appropriate methodology for comparing insect species abundance under variable conditions at a small scale.

MPB dispersal occurs at various scales from within-stand to landscapes, influenced by processes such as weather, habitat connectivity, and forest structure [60-66]. Upon emergence from brood trees, MPB can disperse locally within a stand leading to the expansion of established localized infestations or can disperse over longer distances, leading to the development of new infestations [16,57,63]. A mark and recapture study indicated that 80 to $90 \%$ of the released MPBs were caught within $30 \mathrm{~m}$ of the release site [64]. Another experiment used killed trees as a proxy for beetle dispersal and showed that MPB most commonly dispersed $30 \mathrm{~m}$ to $50 \mathrm{~m}$, regardless of host availability at closer distances [65]. Long distance transport of MPB has also been demonstrated. For example, an examination of MPB dispersal above the forest canopy using radar and aircraft collections, indicated large numbers of MPBs $800 \mathrm{~m}$ above the canopy resulting in estimates that beetles could be transported 30-100 km per day [66]. The height of understory vegetation also influences beetle flight [63]. Open stands allow the establishment and growth of understory trees and shrubs which was evident in the GSL 40 plots, possibly hindering dispersal compared to closed stands with little understory. As traps were passive with no attractants, it is unlikely that beetles were migrating from other areas. The higher numbers of beetles caught in dense stands, prevalent short dispersal distances, and increased understory in more open stands that may interfere with beetle flight, suggest that a large portion of beetles are unlikely to be dispersing from higher density stands but stay within the confines of a shaded environment provided by high canopy cover. This may be the case as long as susceptible trees for infestation are available. It is acknowledged that over the three years of sampling, as tree mortality progressed, the green canopy cover was being replaced by fading and eventually needle shedding, which affected canopy cover but evidently was not sufficient to alter the results.

\subsection{Attack Density, Insect Emergence, and Phloem Consumption}

The higher number of beetles caught dispersing through dense stands did not translate to a higher number of attacks on trees in dense stands as there were more attacks on trees in the less dense GSL 40 stands. MPB host selection includes various processes including random landings, visual cues, tree volatiles identified as signals by the beetles, and gustatory testing [67-71]. It would be reasonable to infer increased attacks by MPB in denser stands associated with a higher likelihood of a beetle landing on a susceptible tree, and less air movement in dense stands [26,72] that may concentrate attractive volatiles. In addition, trees may exhibit higher stress associated with competition resulting in compromised defenses and are perhaps more susceptible to attack [73]. However, a higher number of attacks did not occur in the denser stands.

The number of attacks on trees observed in this study is in general agreement with other studies that have evaluated attack density. A study of lodgepole pine in British Columbia observed 81 attacks per $\mathrm{m}^{2}$ [54]. From work in Oregon, the optimal number of MPBs needed to successfully attack a lodgepole pine tree which will yield the highest ratio of brood per attack was 66-70 attacks per $\mathrm{m}^{2}[74,75]$. Another study conducted in FEF, close to our study sites but about five years earlier when the outbreak was 
in its early stages, indicated that the number of attacks ranged from 65 per $\mathrm{m}^{2}$ to 97 per $\mathrm{m}^{2}$ [34]. The threshold of attacks can vary with the physiological condition of the tree [74-77]. For example, water stress or stand conditions can affect the defenses of the tree [78,79]. These are complex issues affecting attack density that have not been fully resolved. Stand density can be a factor and only this study has sampled trees growing under known stocking levels. Host trees have evolved a suite of highly sophisticated defenses against bark beetles, such as constitutive resin availability, induced defenses after attack, and the production of toxic secondary compounds [70,74,78]. Attacking beetles need to be able to overcome the defensive mechanisms of the tree to successfully colonize and kill the tree, a necessary process for successful reproduction $[74,76]$. To overcome tree defenses, beetles mass attack hosts through a complex pheromone-mediated attraction of hundreds of conspecifics. Moreover, beetles need to prevent overcrowding of the tree to minimize intra-specific competition for resources and accomplish this by the release of anti-aggregation pheromones [57,80]. Numbers of attacks reported in all of these studies likely represent a carrying capacity of beetles in host trees.

Similarly, the higher number of attacks in trees in the GSL 40 plot did not translate to higher numbers of emerging beetles. There was no relationship between tree $\mathrm{dbh}$ and the number of emerging beetles per tree overall or for each GSL. A project in British Columbia reported emergence of about 538 beetles per $\mathrm{m}^{2}$ [54]. Another study indicated and that an attack density of 60 per $\mathrm{m}^{2}$ would yield about 660 pupae per $\mathrm{m}^{2}$ [74]. The other study conducted at FEF reported a higher mean of emergence of about 1140 beetles per $\mathrm{m}^{2}$ with a range from 54 to 2756 beetles per $\mathrm{m}^{2}$ [34]. These numbers broadly agree with this study. As in the studies mentioned above, I report emergence numbers without consideration of the reproduction capacity of the beetles nor competitive interactions occurring in their habitat, among other factors. MPB prefers to attack large-diameter trees as these have thicker phloem which provide more resources for population growth, and phloem thickness is positively correlated with tree diameter $[19,20]$. However, larger more vigorous trees are often better able to defend themselves against bark beetle attacks, but when insect populations are high and the trees are highly stressed, the beetles can effectively overcome the defenses of the large tree to exploit its superior resources [16]. Although the mean dbh of trees in the GSL 40 stands was larger than those in the GSL 120 , the difference was less than $2 \mathrm{~cm}$, unlikely to be sufficient to reflect a difference in emergence from successfully attacked trees. However, the range in tree dbh observed in the GSL 40 was from 20.4 to $29.3 \mathrm{~cm}$ while the size range in the GSL 120 was from 19.7 to $29.3 \mathrm{~cm}$, which would have been a sufficient range to observe higher emergence with increasing tree dbh and thicker phloem [57].

Tree phloem is rich in nutrients and carbohydrates that the insects utilize during development. Phloem is renewed yearly and is enlarged through cell division as influenced by growing season, temperature, water, and nutrient availability [81]. Drought conditions change phloem structure and sap viscosity and decreases translocation of nutrients [82,83]. Considering a large-scale multi-year drought and associated high temperatures, it is possible that phloem thickness and quality were similarly affected in trees across the landscape, minimizing potential differences in brood production, even from larger trees. This may also be supported by the lack of differences observed in phloem consumption in trees growing in the GSL 40 and GSL 120. I found no other studies measuring phloem consumption for comparison. Alternatively, a large insect population active in the area along with an abundance of susceptible trees may have resulted in the beetles becoming less discriminant in host selection. Once trees were selected and successfully attacked, their carrying capacity to support insect populations at the tree level may have had little variability.

The time period of emergence seemed to be unaffected by tree stocking as the pattern was similar in both years. This study seems to be unique in comparing density of attacks, numbers of beetles emerging, and timing of MPB emergence from trees growing under different densities. Observed peak emergence in this study towards the end of July and early to mid-August is consistent with data collected from other sites within the range of the beetle. In western Canada, emergence also typically occurs from late July through mid-August [57] and in Utah and the Colorado Front Range, peak MPB emergence occurred during the same time period $[35,55]$. A number of studies have examined MPB 
attacks and brood production comparing different hosts $[36,84,85]$. Of these, only one examined emergence from field-caged trees for two years across the growing season comparing lodgepole and ponderosa pine in Colorado with no observed differences in timing [36].

\subsection{Probability of Individual Tree Attack}

Enhancing our knowledge of how MPB functions within a lodgepole pine ecosystem in Colorado and other Intermountain west states may lead to the development and refinement of appropriate management strategies that mitigate short and long term affects. Previous studies indicate that reduced bark beetle-caused tree mortality is associated with lower density and thinned lodgepole pine stands $[86,87]$. However, the probability of attack on individual trees within stands has received little attention. It is well documented that MPB prefers over-stocked stands and larger diameter lodgepole pines. In this study, the probability of individual tree attack was determined by the interaction between stocking and tree diameter. The probability of attack on a tree in the GSL 40 plots was from just above 0.6 to slightly less than 0.8 . This probability was lower than in all other GSLs for the larger trees, perhaps because it was less likely for the beetles to locate trees as a result of a reduced number of trees, preference to fly within dense stands, or both. The probability of individual tree attack in the GSL 40 plots was lower in the smaller diameter trees. Although in this study there were no trees $<21 \mathrm{~cm}$ $\mathrm{dbh}$, when present, these smaller trees may be attacked as a function of proximity to larger attacked trees [88]. For the other GSLs in this study, the probability of attack increased with increasing tree diameter as expected. Although a few pairwise differences were observed with tree stocking and tree $\mathrm{dbh}$, no clear pattern was evident. The probability of attack between trees in the GSL 100 and 120 was non-significant for all diameters which may be consistent with a reported threshold for stand infestation of a basal area $>24.4 \mathrm{~m}^{2} \mathrm{ha}^{-1}$ (approximates GSL 100) [38].

An examination of the probability of attack by MPB in ponderosa pine in the Black Hills of South Dakota and Wyoming, USA, indicated that stands with higher basal area in trees $>25 \mathrm{~cm}$ had an increased probability of infestation [89]. At the individual tree level, a tree of any given dbh had a higher probability of attack in denser stands. Although MPB is known to prefer larger trees and denser stands, the distribution of tree sizes within a given stocking level is important in determining the probability of individual tree attack, which may be important to overall stand susceptibility and when assessing how MPB may behave under endemic populations. This is particularly relevant as $\mathrm{MPB}$, within a stand, will disperse to other trees by-passing trees of suitable size for attack [16].

\section{Conclusions}

This study was designed to increase our understanding of MPB behavior in Colorado lodgepole pine forests. Aspects of the biology of MPB observed in this study are generally consistent with the rest of the insect's range. Flight pattern preference within dense stands was consistent with results observed in other locations. The number of attacks and of emerging beetles, in addition to emergence pattern and timing, also seemed consistent with study results in other parts of MPB's range. The examination of the probability of individual tree attack is consistent with the insect's preference for dense stands comprised of larger trees. However, the probability was influenced by the interaction of tree stocking and tree $\mathrm{dbh}$. This suggests that in addition to stocking, the distribution of tree sizes in a stand is a component of the probability of stand infestation and extent of mortality. This interaction warrants further examination to improve our predictive ability of stand infestation and subsequent tree mortality and where beetles may erupt, or both. No effect of tree stocking on brood emergence nor phloem consumption was observed, perhaps due to the large population of insects that masked any potential effects that might have been apparent under lower population levels. Further examination of the effects of host stand structure on the biology of MPB should be conducted, as it has not been adequately examined. Interestingly, a relationship between the number of beetles emerging and tree dbh was not observed. This contrasts with previous studies where increased brood production resulted from larger trees. Recent outbreaks have been characterized as unusually intense 
and extensive. Favorable conditions for increased winter survival of beetles, high tree stress as a result of extreme drought conditions, and an abundance of susceptible hosts likely acted synergistically to produce unusually high beetle populations capable of attacking stressed trees to their optimal carrying capacity and negating other factors that may normally influence brood production.

This study addressed a few aspects of the biology of MPB in Colorado, yet many more are still in need of examination and comparison with other parts of the range, such as MPB developmental rates [90], insect mortality factors [91], MPB interactions with associates such as fungi, mites, nematodes, and microorganisms [92,93], the influence of host secondary chemical composition on host defenses [70], geographic variation in response to semiochemicals [94], interactions with other disturbances [95,96], history of outbreaks at regional and stand levels [28], and the behavior of endemic populations. These data will lead to better management strategies, understanding of responses of forests and bark beetles to climate change, and extending our knowledge of how MPB and interacting disturbances shape forest structure and composition of Colorado's forests.

Funding: This work was funded by the Rocky Mountain Research Station.

Acknowledgments: I would like to thank John Popp, Dan West, and Mario Mora for assisting with field and laboratory work and building emergence cages; Wayne Shepperd and Steve Mata for offering the Fraser plots as a study site; Jeff Witcosky for his feedback on the flight preference study; Jim Ellenwood for photographing bark samples; Scott Baggett for statistical support; Bob Cain, Laurie Huckaby, and Steve Munson for reviewing previous versions of this manuscript; and the personnel at Fraser Experimental Forest and the Colorado State Forest for access to the study sites; and to three anonymous reviewers that provided valuable comments that improved the manuscript considerably.

Conflicts of Interest: The author declares no conflict of interest.

\section{Appendix A}

Table A1. ANOVA table for mountain pine beetle flight across stands of different Growing Stock Levels (GSL).

\begin{tabular}{ccccc}
\hline \multicolumn{5}{c}{ Test of Fixed Effects } \\
\hline Effect & Num DF & Den DF & F-Value & $\boldsymbol{P r}$ \\
\hline GSL & 2 & 35.9 & 14.5 & $<0.0001$ \\
Year & 2 & 35.9 & 17.5 & $<0.0001$ \\
GSL Year & 4 & 35.39 & 0.4 & 0.78 \\
\hline
\end{tabular}

NUM DF = Numerator Degrees of Freedom; DEN DF = Denominator Degrees of Freedom; $\mathrm{Pr}=$ Probability. The asterisk between GSL*Year means interaction (again commonly used standard usage).

Table A2. ANOVA table for the Growing Stock Level (GSL) fixed effect for number of attacks, number of emerging beetles, diameter at breast height $(\mathrm{dbh})$, and phloem consumption in their respective analysis.

\begin{tabular}{cccccc}
\hline & \multicolumn{5}{c}{ Test of Fixed Effects } \\
\hline Response & Effect & Num DF & Den DF & F-Value & Pr \\
\hline Number of attacks & GSL & 1 & 70.0 & 10.4 & 0.002 \\
No. of emerging beetles & GSL & 1 & 76.9 & 0.56 & 0.46 \\
dbh & GSL & 1 & 76.8 & 8.8 & 0.004 \\
Phloem consumption & GSL & 1 & 36 & 1.3 & 0.26 \\
\hline
\end{tabular}

Table A3. ANOVA table for the relationship between diameter at breast height ( $\mathrm{dbh}$ ) and the number of emerging mountain pine beetles.

\begin{tabular}{ccccc}
\hline \multicolumn{5}{c}{ Test of Fixed Effects } \\
\hline Effect & Num DF & Den DF & F-Value & $\boldsymbol{P r}$ \\
\hline dbh & 1 & 75.4 & 0.07 & 0.79 \\
GSL & 1 & 74.9 & 0.30 & 0.59 \\
dbh $^{*}$ GSL & 1 & 74.9 & 0.24 & 0.63 \\
\hline
\end{tabular}


Table A4. ANOVA table for probability of attack of individual trees.

\begin{tabular}{ccccc}
\hline \multicolumn{5}{c}{ Test of Fixed Effects } \\
\hline Effect & Num DF & Den DF & $\boldsymbol{F}$-Value & $\boldsymbol{P r}$ \\
\hline dbh & 1 & 1407 & 105.4 & $<0.0001$ \\
GSL & 3 & 1407 & 8.2 & $<0.0001$ \\
dbh $^{*}$ GSL & 3 & 1407 & 13.1 & $<0.0001$ \\
\hline
\end{tabular}

\section{References}

1. Wood, S.L. The bark and ambrosia beetles of North and Central America (Coleoptera: Scolytidae), a taxonomic monograph. Great Basin Nat. Mem. 1982, 6, 1359.

2. Costello, S.L.; Schaupp, W.C. First Nebraska state record of the mountain pine beetle, Dendroctonus ponderosae Hopkins (Coleoptera: Curculionidae: Scolytinae). Coleopts. Bull. 1988, 65, 21-23. [CrossRef]

3. De la Giroday, H.C.; Carroll, A.L.; Aukema, B.H. Breach of the northern Rocky Mountain geoclimatic barrier: Initiation of range expansion by the mountain pine beetle. J. Biogeogr. 2012, 39, 112-1123. [CrossRef]

4. Carroll, A.L.; Taylor, S.W.; Régnière, J.; Safranyik, L. Effects of climate change on range expansion by the mountain pine beetle in British Columbia. In Mountain Pine Beetle Symposium: Challenges and Solutions, Kelowna, British Columbia, Canada, 30-31 October 2003; Shore, T.L., Brooks, J.E., Stone, J.E., Eds.; Natural Resources Canada, Canadian Forest Service, Pacific Forestry Centre: Victoria, BC, Canada, 2003; pp. 223-232.

5. Cullingham, C.I.; Cooke, J.E.K.; Dang, S.; Davis, C.S.; Cooke, B.J.; Coltman, D.W. Mountain pine beetle host-range expansion threatens the boreal forest. Mol. Ecol. 2011, 20, 2157-2171. [CrossRef] [PubMed]

6. Furniss, M.M.; Schenk, J.A. Sustained natural infestations by the mountain pine beetle in seven new Pinus and Picea hosts. J. Econ. Entomol. 1969, 62, 518-519. [CrossRef]

7. Negrón, J.F.; Fettig, C.J. Mountain pine beetle, a major disturbance agent in US western coniferous forests: A synthesis of the state of knowledge. For. Sci. 2014, 60, 409-413. [CrossRef]

8. Raffa, K.F.; Aukema, B.H.; Bentz, B.J.; Carroll, A.L.; Hicke, J.A.; Turner, M.G.; Romme, W.H. Cross-scale drivers of natural disturbances prone to anthropogenic amplification: Dynamics of biome-wide bark beetle eruptions. Bioscience 2008, 58, 501-518. [CrossRef]

9. Dordel, J.; Feller, M.C.; Simard, S.W. Effects of mountain pine beetle (Dendroctonus ponderosae Hopkins) infestations on forest stand structure in the southern Canadian Rocky Mountains. For. Ecol. Manag. 2008, 255, 3563-3570. [CrossRef]

10. Axelson, J.N.; Alfaro, R.I.; Hawkes, B.C. Influence of fire and mountain pine beetle on the dynamics of lodgepole pine stands in British Columbia, Canada. For. Ecol. Manag. 2009, 257, 1874-1882. [CrossRef]

11. Klutsch, J.G.; Negrón, J.F.; Costello, S.L.; Rhoades, C.C.; West, D.R.; Popp, J.; Caissie, R. Stand characteristics and downed woody debris accumulations associated with a mountain pine beetle (Dendroctonus ponderosae Hopkins) outbreak in Colorado. For. Ecol. Manag. 2009, 258, 641-649. [CrossRef]

12. Negrón, J.F.; Cain, B. Mountain pine beetle in Colorado: A story of changing forests. J. For. 2018. [CrossRef]

13. Colorado State Forest Service. 2014 Report on the Health of Colorado's Forests. Colorado State Forest Service, Fort Collins, CO, USA. Available online: www.csfs.colostate.edu (accessed on 15 May 2018).

14. Amman, G.D.; McGregor, M.D.; Cahill, D.B.; Klein, W.H. Guidelines for Reducing Losses of Lodgepole Pine to the Mountain Pine Beetle in Unmanaged Stands in the Rocky Mountains; General Technical Report, INT-GTR-262; US Department of Agriculture, Forest Service, Intermountain Forest and Range Experiment Station: Ogden, UT, USA, 1977; p. 19.

15. Shore, T.L.; Safranyik, L. Susceptibility and Risk Rating Systems for the Mountain Pine Beetle in Lodgepole Pine Stands; Information Report, BC-X-336; Forestry Canada, Pacific Forestry Centre: Victoria, BC, Canada, 1992; p. 12.

16. Boone, C.K.; Aukema, B.H.; Bohlmann, J.; Carroll, A.L.; Raffa, K.F. Efficacy of tree defense physiology varies with bark beetle population density: A basis for positive feedback in eruptive species. Can. J. For. Res. 2011, 41, 1174-1188. [CrossRef]

17. Waring, R.H.; Pitman, G.B. Modifying lodgepole pine stands to change susceptibility to mountain pine beetle attack. Ecology 1985, 66, 889-897. [CrossRef] 
18. Safranyik, L.; Shrimpton, D.M.; Whitney, H.S. Management of Lodgepole Pine to Reduce Losses from the Mountain Pine Beetle; Forestry Technical Report, 1; Environment Canada, Forestry Service, Pacific Forest Research Centre: Victoria, BC, Canada, 1974; p. 24.

19. Amman, G.D. Mountain pine beetle brood production in relation to thickness of lodgepole pine phloem. J. Econ. Entomol. 1972, 65, 138-140. [CrossRef]

20. Shrimpton, D.M.; Thomson, A.J. Relationship between phloem thickness and lodgepole pine growth characteristics. Can. J. For. Res. 1985, 15, 1004-1008. [CrossRef]

21. Bartos, D.L. Microclimate as a factor in lodgepole pine (Pinus contorta Douglas) stands and tree selection by mountain pine beetles (Dendroctonus ponderosae Hopkins). In Proceedings of IUFRO Working Party and XVII International Congress of Entomology, Blacksburg, VA, USA, 4 July; Payne, T.L., Saarenmaa, H., Eds.; Department of Entomology, Virginia Tech University: Blacksburg, VA, USA, 1988; pp. 215-230.

22. Bartos, D.L.; Amman, G.D. Microclimate: An Alternative to Tree Vigor as a Basis for Mountain Pine Beetle Infestations; Research Paper, INT-RP-400; US Department of Agriculture, Forest Service, Intermountain Forest and Range Experiment Station: Ogden, UT, USA, 1989; p. 10.

23. Amman, G.D.; Logan, J.A. Silvicultural control of mountain pine beetle: Prescriptions and the influence of microclimate. Am. Entomol. 1998, 44, 166-177. [CrossRef]

24. Geiszler, D.R.; Gara, R.W. Mountain pine beetle attack dynamics in lodgepole pine. In Theory and Practice of Mountain Pine Beetle Management in Lodgepole Pine Forests, Symposium Proceedings, Pullman, WA, USA, 25-27 April 1978; Berryman, A.A., Amman, G.D., Stark, R.W., Eds.; University of Idaho Forest, Wildlife and Range Experiment Station: Moscow, ID, USA; U.S. Department of Agriculture, Forest Service, Forest Insect and Disease Research: Washington, DC, USA, 1978; pp. 182-187.

25. Whitehead, R.J.; Russo, G.L. "Beetle-Proofed" Lodgepole Pine Stands in Interior British Columbia have Less Damage from Mountain Pine Beetle; Information Report, BC-X-402; Natural Resources Canada, Canadian Forest Service, Pacific Forestry Centre: Victoria, BC, Canada, 2005; p. 17.

26. Thistle, H.W.; Peterson, H.; Allwine, G.; Lamb, B.; Strand, T.; Holsten, E.H.; Shea, P.J. Surrogate pheromone plumes in three forest trunk spaces: Composite statistics and case studies. For. Sci. 2004, 50, 610-625.

27. Schmid, J.M.; Mata, S.A. Natural Variability of Specific Forest Insect Populations and their Associated Effects in Colorado; General Technical Report, RM-GTR-275; US Department of Agriculture, Forest Service, Rocky Mountain Forest and Range Experiment Station: Fort Collins, CO, USA, 1996; p. 14.

28. Jarvis, D.S.; Kulakowski, D. Long-term history and synchrony of mountain pine beetle outbreaks in lodgepole pine forests. J. Biogeogr. 2015, 42, 1029-1039. [CrossRef]

29. McCambridge, W.F.; Hawksworth, F.G.; Edminster, C.B.; Laut, J.G. Ponderosa Pine Mortality Resulting from a Mountain Pine Beetle Outbreak; Research Paper, RM-RP-235; US Department of Agriculture, Forest Service, Rocky Mountain Forest and Range Experiment Station: Fort Collins, CO, USA, 1982; p. 7.

30. Negrón, J.F.; Popp, J.B. Probability of ponderosa pine infestation by mountain pine beetle in the Colorado Front Range. For. Ecol. Manag. 2004, 191, 17-27. [CrossRef]

31. Colorado State Forest Service. 2011 Report on the Health of Colorado's Forests; Colorado State Forest Service, Fort Collins, CO, USA. Available online: www.csfs.colostate.edu (accessed on 15 April 2018).

32. Alexander, R.R.; Taclle, D.; Dahms, W.G. Site Indices for Lodgepole Pine, with Corrections for Stand Density: Methodology; Research Paper, RM-RP-29; US Department of Agriculture, Forest Service, Rocky Mountain Forest and Range Experiment Station: Fort Collins, CO, USA, 1967; p. 18.

33. Huckaby, L.S.; Moir, W.H. Forest communities at Fraser Experimental Forest, Colorado. Southwest Nat. 1998, 43, 201-208.

34. Tishmack, J.; Mata, S.A.; Schmid, J.M. Mountain Pine Beetle Emergence from Lodgepole Pine at Different Elevations Near Fraser, CO; Research Note, RMRS-RN-27; US Department of Agriculture, Forest Service, Rocky Mountain Research Station: Fort Collins, CO, USA, 2005; p. 5.

35. McCambridge, W.F. Emergence Period of Black Hills Beetles from Ponderosa Pine in the Central Rocky Mountains; Research Note, RM-RN-32; US Department of Agriculture, Forest Service, Rocky Mountain Forest and Range Experiment Station: Fort Collins, CO, USA, 1964; p. 4.

36. West, D.R.; Briggs, J.S.; Jacobi, W.R.; Negrón, J.F. Mountain pine beetle host selection between lodgepole and ponderosa pines in the southern Rocky Mountains. Environ. Entomol. 2016, 45, 127-141. [CrossRef] [PubMed] 
37. West, D.R.; Briggs, J.S.; Jacobi, W.R.; Negrón, J.F. Mountain pine beetle-caused mortality over eight years in two pine hosts in mixed-conifer stands of the southern Rocky Mountains. For. Ecol. Manag. 2014, 334, 321-330. [CrossRef]

38. Mata, S.A.; Schmid, J.A.; Olsen, W.K. Growth of Lodgepole Pine Stands and its Relation to Mountain Pine Beetle Susceptibility; Research Paper, RMRS-RP-42; US Department of Agriculture, Forest Service, Rocky Mountain Research Station: Fort Collins, CO, USA, 2003; p. 19.

39. Negrón, J.F.; Klutsch, J.G. Probability of Infestation and Extent of Mortality Models for Mountain Pine Beetle in Lodgepole Pine Forests in Colorado; Research Note, RMRS-RN-77; US Department of Agriculture, Forest Service, Rocky Mountain Research Station: Fort Collins, CO, USA, 2017; p. 13.

40. Ross, D.; Daterman, G. Using pheromone-baited traps to control the amount and distribution of tree mortality during outbreaks of the Douglas-fir beetle. For. Sci. 1997, 43, 65-70.

41. Furniss, M.M.; Kegley, S.J. Douglas-fir Beetle, Forest Insect and Disease Leaflet 5; US Department of Agriculture, Forest Service, Pacific Northwest Region (R6): Portland, Oregon, USA, 2014; p. 12.

42. Lessard, E.D.; Schmid, J.M. Emergence, attack densities, and host relationships for the Douglas-fir beetle (Dendroctonus pseudotsugae Hopkins) in northern Colorado. Great Basin Nat. 1990, 50, 333-338.

43. Negrón, J.F.; Schaupp, W.C., Jr.; Pederson, L. Flight periodicity of the Douglas-fir beetle, Dendroctonus pseudotsugae Hopkins (Coleoptera: Curculionidae: Scolytinae) in Colorado, U.S.A. Coleopts. Bull. 2011, 65, 182-184.

44. Bentz, B.J.; Bracewell, R.R.; Mock, K.E.; Pfrender, M.E. Genetic architecture and phenotypic plasticity of thermally-regulated traits in an eruptive species, Dendroctonus ponderosae. Evol. Ecol. 2011, 25, 1269-1288. [CrossRef]

45. Bentz, B.J.; Logan, J.A.; Vandygriff, J.C. Latitudinal variation in Dendroctonus ponderosae (Coleoptera: Scolytidae) development time and adult size. Can. Entomol. 2001, 133, 375-387. [CrossRef]

46. Rehfeldt, G.E. A Spline Model of Climate for the Western United States; General Technical Report, RMRS-GTR-165; US Department of Agriculture, Forest Service, Rocky Mountain Research Station: Fort Collins, CO, USA, 2006; p. 21.

47. Allen, C.D.; Macalady, A.K.; Chenchouni, H.; Bachelet, D.; McDowell, N.; Vennetier, M.; Kitzberger, T.; Rigling, A.; Breshears, D.D.; Hogg, E.H.; et al. Global overview of drought and heat-induced tree mortality reveals emerging climate change risks for forests. For. Ecol. Manag. 2010, 259, 660-684. [CrossRef]

48. Bentz, B.J.; Regniere, J.; Fettig, C.J.; Hansen, E.M.; Hayes, J.L.; Hicke, J.A.; Kelsey, R.G.; Negrón, J.F.; Seybold, S.J. Climate change and bark beetles of the western United States and Canada: Direct and indirect effects. Bioscience 2010, 60, 602-613. [CrossRef]

49. Seidl, R.; Spies, T.A.; Peterson, D.L.; Stephens, S.L.; Hicke, J.A. Searching for resilience: Addressing the impacts of changing disturbance regimes on forest ecosystem services. J. Appl. Ecol. 2015, 53, 120-129. [CrossRef]

50. Prism Climate Group. Available online: http://prism.oregonstate.edu/ (accessed on 28 April 2015).

51. Myers, C.A. Growing Stock Levels in Even-Aged Ponderosa Pine; Research Paper, RM-RP-33; US Department of Agriculture, Forest Service, Rocky Mountain Forest and Range Experiment Station: Fort Collins, CO, USA, 1967; p. 8.

52. SAS Institute. SAS/STAT 9.4 User's Guide; SAS Institute: Cary, NC, USA, 2016.

53. Lindgren, B.S. A multiple funnel trap for scolytid beetles (Coleoptera). Can. Entomol. 1983, 115, $299-302$. [CrossRef]

54. Reid, R.W. Biology of the mountain pine beetle, Dendroctonus monticolae Hopkins, in the east Kootenay region of British Columbia. III. Interaction between the beetle and its host, with emphasis on brood mortality and survival. Can. Entomol. 1963, 95, 225-238. [CrossRef]

55. Rasmussen, L.A. Emergence and Attack Behavior of the Mountain Pine Beetle in Lodgepole Pine; Research Note, INT-RN-297; US Department of Agriculture, Forest Service, Intermountain Forest and Range Experiment Station: Ogden, UT, USA, 1980; p. 7.

56. Negrón, J.F.; Shepperd, W.D.; Mata, S.A.; Popp, J.B.; Asherin, L.A.; Schoettle, A.W.; Schmid, J.M.; Leatherman, D.A. Solar Treatment for Reducing Survival of Mountain Pine Beetle in Infested Ponderosa and Lodgepole Pine Logs; Research Paper, RMRS-RP-30; US Department of Agriculture, Forest Service, Rocky Mountain Research Station: Fort Collins, CO, USA, 2001; p. 11. 
57. Safranyik, L.; Carroll, A.L. The biology and epidemiology of the mountain pine beetle in lodgepole pine forests. In The Mountain Pine Beetle A Synthesis of Biology, Management, and Impacts on Lodgepole Pine; Safranyik, L., Wilson, B., Eds.; Natural Resources Canada, Canadian Forest Service, Pacific Forestry Centre: Victoria, BC, Canada, 2006; pp. 3-66.

58. Schmitz, R.F.; McGregor, M.D.; Amman, G.D.; Oakes, R.D. Effect of partial cutting treatments of lodgepole pine stands on the abundance and behavior of flying mountain pine beetles. Can. J. For. Res. 1989, 19, 566-574. [CrossRef]

59. Hindmarch, T.D.; Reid, M.L. Thinning of mature lodgepole pine stands increases scolytid bark beetle abundance and diversity. Can. J. For. Res. 2001, 31, 1502-1512. [CrossRef]

60. Aukema, B.H.; Carroll, A.L.; Zhu, J.; Raffa, K.F.; Sickley, T.A.; Taylor, S.W. Landscape level analysis of mountain pine beetle in British Columbia, Canada: Spatiotemporal development and spatial synchrony within the present outbreak. Ecography 2006, 29, 427-441. [CrossRef]

61. Aukema, B.H.; Carroll, A.L.; Zheng, Y.; Zhu, J.; Raffa, K.F.; Moore, D.R.; Stahl, K.; Taylor, S.W. Movement of outbreak populations of mountain pine beetle: Influences of spatiotemporal patterns and climate. Ecography 2008, 31, 348-358. [CrossRef]

62. Chapman, T.B.; Veblen, T.T.; Schoennagel, T. Spatiotemporal patterns of mountain pine beetle activity in the southern Rocky Mountains. Ecology 2012, 93, 2175-2185. [CrossRef]

63. Safranyik, L.; Silversides, R.; McMullen, L.H.; Linton, D.A. An empirical approach to modeling the local dispersal of the mountain pine beetle (Dendroctonus ponderosae Hopk.) (Col., Scolytidae) in relation to sources of attraction, wind direction, and speed. J. Appl. Entomol. 1989, 108, 498-511. [CrossRef]

64. Safranyik, L.; Linton, D.A.; Silversides, R.; McMullen, L.H. Dispersal of released mountain pine beetles under the canopy of a mature lodgepole pine stand. J. Appl. Entomol. 1992, 113, 441-450. [CrossRef]

65. Robertson, C.; Nelson, T.A.; Boots, B. Mountain pine beetle dispersal: The spatial-temporal interaction of infestations. For. Sci. 2007, 53, 395-405.

66. Jackson, P.L.; Straussfogel, D.; Lindgren, B.S.; Mitchell, S.; Murphy, B. Radar observation of aerial capture of mountain pine beetle, Dendroctonus ponderosae Hopk. (Coleoptera: Scolytidae) in flight above the forest canopy. Can. J. For. Res. 2008, 38, 2313-2327. [CrossRef]

67. Hynum, B.G.; Berryman, A.A. Dendroctunus ponderosae (Coleoptera: Scolytidae): Pre-aggregation landing and gallery initiation on lodgepole pine. Can. Entomol. 1980, 112, 185-191. [CrossRef]

68. Campbell, S.A.; Borden, J.H. Integration of visual and olfactory cues of hosts and non-hosts by three bark beetles (Coleoptera: Scolytidae). Ecol. Entomol. 2006, 31, 437-449. [CrossRef]

69. Pureswaran, D.S.; Borden, J.H. Primary attraction and kairomonal host discrimination in three species of Dendroctonus (Coleoptera: Scolytidae). Agric. For. Entomol. 2005, 7, 219-230. [CrossRef]

70. Raffa, K.F.; Aukema, B.H.; Erbilgin, N.; Klepzig, K.D.; Wallin, K.F. Interactions among conifer terpenoids and bark beetles across multiple levels of scale: An attempt to understand links between population patterns and physiological processes. Recent Adv. Phytochem 2005, 39, 80-118.

71. Raffa, K.F.; Berryman, A.A. Gustatory cues in the orientation of Dendroctonus ponderosae Coleoptera: Scolytidae) to host trees. Can. Entomol. 1982, 114, 97-104. [CrossRef]

72. Edburg, S.L.; Allwine, G.; Lamb, B.; Stock, D.; Thistle, H.; Peterson, H.; Strom, B. A simple model to predict scalar dispersion within successively thinned loblolly pine canopy. J. Appl. Meteorol. Clim. 2010, 49, 1913-1926. [CrossRef]

73. Fettig, C.J.; Klepzig, K.D.; Billings, R.F.; Munson, A.S.; Nebeker, T.E.; Negrón, J.F.; Nowak, J.T. The effectiveness of vegetation management practices for prevention and control of bark beetle infestations in coniferous forests of the western and southern United States. For. Ecol. Manag. 2007, 238, 24-53. [CrossRef]

74. Raffa, K.F.; Berryman, A.A. The role of host plant resistance in the colonization behavior and ecology of bark beetles (Coleoptera: Scolytidae). Ecol. Monogr. 1983, 53, 27-49. [CrossRef]

75. Raffa, K.F. Mixed messages across multiple trophic levels: The ecology of bark beetle chemical communication systems. Chemoecology 2001, 11, 49-65. [CrossRef]

76. Berryman, A.A. Resistance to conifers to invasion by bark beetle-fungal associations. BioScience 1972, 22, 598-602. [CrossRef]

77. Raffa, K.F.; Powell, E.N.; Townsend, P.A. Temperature-driven range expansion of an irruptive insect heightened by weakly coevolved plant defenses. Proc. Natl. Acad. Sci. USA. 2013, 110, 2193-2198. [CrossRef] [PubMed] 
78. Franceschi, V.R.; Krokene, P.; Christiansen, E.; Krekling, T. Anatomical and chemical defenses of conifer bark against bark beetles and other pests. New Phytol. 2005, 167, 353-376. [CrossRef] [PubMed]

79. Kolb, T.E.; Fettig, C.J.; Ayres, M.P.; Bentz, B.J.; Hicke, J.A.; Mathiasen, R.; Stewart, J.E.; Weed, A.S. Observed and anticipated impacts of drought on forest insects and diseases in the United States. For. Ecol. Manag. 2016, 380, 321-334. [CrossRef]

80. Wood, D.L. The role of pheromones, kairomones, and allomones in the host selection and colonization behavior of bark beetles. Ann. Rev. Entomol. 1982, 27, 411-446. [CrossRef]

81. Holtta, T.; Kurppa, M.; Nikinmaa, E. Scaling of xylem and phloem transport capacity and resource usage with tree size. Front. Plant Sci. 2013, 4, 1-19. [CrossRef] [PubMed]

82. Dannoura, M.; Epron, D.; Desalme, D.; Massonnet, C.; Tsuji, S.; Plain, C.; Priault, P.; Gérant, D. The impact of prolonged drought on phloem anatomy and phloem transport in young beech trees. Tree Physiol. 2018. [CrossRef] [PubMed]

83. Sevanto, S. Drought impacts on phloem transport. Curr. Opin. Plant Biol. 2018, 43, 76-81. [CrossRef] [PubMed]

84. Cerezke, H.F. Egg gallery, brood production, and adult characteristics of mountain pine beetle, Dendroctonus ponderosae Hopkins (Coleoptera: Scolytidae), in three pine hosts. Can. Entomol. 1995, 127, 955-965. [CrossRef]

85. Dean, D.K. Host utilization by the mountain pine beetle, Dendroctonus ponderosae Hopkins (Coleoptera: Scolytidae), in mixed stands of limber pine, Pinus flexilis James, and lodgepole pine, Pinus contorta latifolia Engelmann. Master's Thesis, University of Wyoming, Laramie, WY, USA, 2007.

86. Cole, W.E.; Cahill, D.B. Cutting strategies can reduce probabilities of mountain pine beetle epidemics in lodgepole pine. J. For. 1976, 74, 294-297.

87. McGregor, M.D.; Amman, G.D.; Schmitz, R.F.; Oakes, R.D. Partial cutting lodgepole pine stands to reduce losses to the mountain pine beetle. Can. J. For. Res. 1987, 17, 1234-1239. [CrossRef]

88. Mitchell, R.G.; Preisler, H.K. Analysis of spatial patterns of lodgepole pine attacked by outbreak populations of the mountain pine beetle. For. Sci. 1991, 37, 1390-1408.

89. Negrón, J.F.; Allen, K.; Cook, B.; Withrow, J.R. Susceptibility of ponderosa pine, Pinus ponderosa (Dougl. ex Laws.), to mountain pine beetle, Dendroctonus ponderosae Hopkins, attack in uneven-aged stands in the Black Hills of South Dakota and Wyoming, USA. For. Ecol. Manag. 2008, 254, 327-334. [CrossRef]

90. Powell, J.A.; Logan, J.A. Insect seasonality: Circle map analysis of temperature-driven life cycles. Theor. Popul. Biol. 2005, 67, 161-179. [CrossRef] [PubMed]

91. Amman, G.D. Mountain pine beetle (Coleptera: Scolytidae) mortality in three types of infestations. Environ. Entomol. 1984, 13, 184-191. [CrossRef]

92. Mercado, J.E.; Hofstetter, R.W.; Reboletti, D.M.; Negrón, J.F. Phoretic symbionts of the mountain pine beetle (Dendroctonus ponderosae Hopkins). For. Sci. 2014, 60, 512-526. [CrossRef]

93. Adams, A.S.; Aylward, F.O.; Adams, S.M.; Erbilgin, N.; Aukema, B.H.; Currie, C.R.; Suen, G.; Raffa, K.F. Mountain pine beetles colonizing historical and naïve host trees are associated with a bacterial community highly enriched in genes contributing to terpene metabolism. Appl. Environ. Micr. 2013, 79, 3468-3475. [CrossRef]

94. Hofstetter, R.W.; Chen, Z.; Gaylord, M.L.; McMillin, J.D.; Wagner, M.R. Synergistic effects of a-pinene and exo-brevicomin on pine bark beetles and associated insects in Arizona. J. Appl. Entomol. 2008, 132, 387-397. [CrossRef]

95. Klutsch, J.G.; Battaglia, M.A.; West, D.R.; Costello, S.L.; Negrón, J.F. Evaluating potential fire behavior in lodgepole pine-dominated forests after a mountain pine beetle epidemic in north-central Colorado. West. Appl. For. 2011, 26, 101-109.

96. Kulakowski, D.; Jarvis, D.; Veblen, T.T.; Smith, J. Stand-replacing fires reduce susceptibility of lodgepole pine to mountain pine beetle outbreaks in Colorado. J. Biogeogr. 2012, 39, 2052-2060. [CrossRef]

(C) 2018 by the author. Licensee MDPI, Basel, Switzerland. This article is an open access article distributed under the terms and conditions of the Creative Commons Attribution (CC BY) license (http:/ / creativecommons.org/licenses/by/4.0/). 